\title{
Price Is a Better Climate Commitment
}

\section{PETER CRAMTON AND STEVEN STOFT}

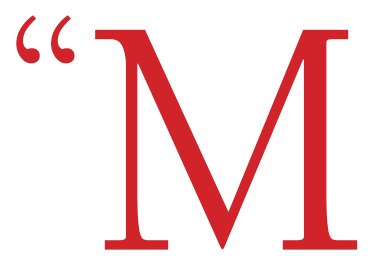

itigation. Transparency. Financing." That was President Obama's formula for Copenhagen. While emission caps may appear transparent, their consequences are opaque, and they impose financial risk rather than provide financing. Caps satisfy only the first part of Obama's formula. Moreover they have been rejected once again by all developing countries, which will leave the bulk of emission increases in the coming years uncapped and outside of any carbon pricing regime.

Peter Cramton is Professor of Economics at the University of Maryland and an expert on market design; Steven Stoft is Director of the Global Energy Policy Center and the author of Carbonomics. Their research on climate policy can be found at www.global-energy.org.

๑) The Berkeley Electronic Press
To correct this vast omission, we propose a new pair of commitments-a commitment to a binding carbon-price target and to a Green Fund financed by a form of carbon pricing. Together these satisfy all three parts of Obama's formula and solve many of the problems caps create. The result is a price mechanism that brings countries together instead of pushing them apart.

The price commitment does not interfere with distant aspirational goals. In fact, because the price commitment facilitates agreement and then reinforces it with incentives, it provides real hope that such aspirations may be realized.

The question of which international commitment is preferable, a cap or a price, should not be confused with the domestic debate over whether to use cap and trade, a carbon tax, or some mix of the two. Either commitment, to a cap or a price, can be met with either domestic policy. So under a price commitment, industrialized countries can adopt cap and trade, while developing countries can tax fossil fuels. With either domestic policy, performance is rewarded on the basis of the country's carbon price relative to the global price target.

\section{A PRICE TARGET IS ESSENTIAL}

Uch has been invested in promoting inIternational emission targets, but pressure to accept emission targets has caused an increasingly acrimonious divide between rich and poor nations. And nothing indicates that the next thirteen years of negotiation will prove more productive than the previous thirteen. Switching to a global price target

The Economists' Voice www.bepress.com/ev February, 2010 
eliminates the issues developing countries have with caps and opens up the possibility of a successful, binding international agreement. This is no minor distinction between better and best.

In spite of this stark difference, one important similarity should be kept in mind. Emission caps that are implemented with cap and trade work through the price mechanism. A tight cap causes high allowance prices, and companies react to those prices. Under cap and trade or fossil-fuel taxes, the carbon price is the best summary measure of a country's incentive to abate emissions. Besides this similarity, a price target has a number of crucial advantages.

A price target avoids the imposition of caps on developing countries. The United States favors national caps based on trendline emissions, which would mean capping India at per-capita emission levels not seen in the United States in well over one hundred years. But developing countries ask, "By what right are the developed countries entitled to pollute more than we are, simply because they polluted more in the past?"1 By contrast, a price target does not limit India to emit any less than the United States, and instead asks for effort levels that are proportional to emissions, and hence closely correlated with ability to pay.

A global price target facilitates negotiations, because the focus is on a single target that embodies the common objective of abating world emissions. If a single global cap could control the sum of all national caps, negotiating that single cap would have the same negotiating advantage as that of a global price target. But negotiating a global price target sets all national price targets, while choosing a single global cap tells us nothing about national caps. And negotiating individual national caps is contentious because caps are equivalent to money, so each country desires a higher cap for itself and lower caps for others.

Were all countries identical, then the negotiation would be relatively straightforward under either price or cap, since setting the same national cap for each country would be focal. However, the global debate is characterized by extreme asymmetries in wealth, current emissions, and historical emissions. It is precisely these asymmetries that make negotiating national caps difficult.
A third advantage is that a price target is more easily enforced because it is a steady commitment. Performance can be assessed and rewarded on a continuous basis. A commitment to distant caps is much more apt to break down when procrastination is followed by the day of reckoning.

\section{A PRICE TARGET REDUCES RISK}

Relative to a global cap, a price target reRduces a country's risk of commitment. The cost of unexpected growth is much higher under commitment to a cap than under a price target.

As an example, consider the impact on China of unexpected emissions growth under a cap and under a price commitment. First, suppose that with expected growth the global cap would result in a carbon price of $\$ 30$ per ton, and that at that price China's cap would equal its emissions. Also suppose the price target is $\$ 30$ per ton. In this expected case, the two commitments have the same cost.

But what if China's emissions grow by a billion tons more than expected, while world emissions change as expected? Under either commitment, the world-price of carbon 
remains at $\$ 30$, and therefore China's price also remains at $\$ 30$ per ton. So the abatement costs are identical. Also, domestic carbon revenues under a cap or taxes are equal. The only difference is that under a cap, China must buy one billion carbon permits from other countries at a cost of $\$ 30$ billion; whereas, with taxes, the $\$ 30$ billion stays within China.

Hence, with unexpectedly high growth, commitment to a cap imposes an additional $\$ 30$ billion cost to buy international carbon permits. Such purchases could also impose a high political cost, especially if the permits are purchased from countries that have historically emitted more than China. Between 2000 and 2010, China's unanticipated emissions growth was about twice as much as assumed here.

\section{THE PRICE TARGET AND THE GREEN FUND}

ur proposal comprises two interrelated parts, the first of which is commitment by participating countries to a single global price target, which is expected to increase over time. This commitment requires that a country either collect carbon revenue equal to the price target times the country's total emissions or pay others to make up the carbon-revenue shortfall. The forms of revenue collection utilized, such as taxing fossil fuels or auctioning allowances, are left up to the country. Certain other polices, discussed below, also count towards revenue. The revenues collected are retained by the country.

Especially with a domestic cap and trade policy, there is a possibility that the country's revenues may be above or below the target. To motivate the country to set a cap (or a tax) consistent with the target price, the Pricing Incentive pays $Z \times$ (excess carbon revenue), where $Z$, the incentive strength, may be about 10 percent. Since each country keeps the carbon revenue it collects but looses any negative Pricing Incentive payment, an incentive like 10 percent probably is sufficient to achieve global carbon revenues consistent with the price target. These incentive payments also mimic the flexibility of international trade in carbon allowances, which allows countries to miss their domestic emission targets and instead buy or sell carbon permits on the international market.

If global revenues are too low, the incentive strength is increased; if global revenues are too high, the incentive strength is decreased. These adjustments assure average carbon pricing consistent with the price target as well as budget balance over time. ${ }^{2}$

The second part of the proposal is the Green Fund, which provides: equity transfers, improved pricing compliance, and motivation for non-price climate policies. Developing countries with low per-capita emissions would be justifiably reluctant to commit to a price target without some further inducement. A Green Fund provides this by rewarding low-emission countries for verified compliance with the global pricing target. Fully-compliant countries with emissions per-capita that are below the global average by $D$ tons per person receive a per-capita payment of $G \times D$. The incentive strength, $G$, might be, for example, $\$ 2$ per ton. Countries with above-average emissions make payments according to the same formula, which results in a balanced Green Fund budget.

The United States, which emits about 20 tons per capita per year $\left(\mathrm{CO}_{2}\right.$ only) compared to the global average of 5 tons per year, would pay about $(20-5) \times 2=\$ 30$ per person per year into the fund. India, with per-capita 
emissions of about 1 ton per year would receive a payment of $(5-1) \times 2=\$ 8$ per person from the fund. In the case of India, the Green Fund payment more than offsets India's abatement cost caused by complying with a \$30-per-ton carbon tax.

The full mechanism depends on just two key, internationally-negotiated parameters: the price target (illustrated at $\$ 30$ per ton) and the Green Fund incentive (illustrated at $\$ 2$ per ton). The global carbon price motivates private emission reductions, while Green Fund payments encourage national reduction programs. The Pricing Incentive ensures performance globally. Secondary enforcement can come from trade sanctions, but this typically would be unnecessary.

\section{EMISSION 'CERTAINTY'}

— mission targets are said to provide - certainty. But remote and moving targets are most accurately hit by guided systems and not by an unguided system such as a cap set 40 years in advance. The standard approach is to use periodic estimates of the location of the target and the trajectory of the system to adjust one or more control variables, such as price. The idea that a newly formed world organization might set a cap on all the world's emissions that would hold for forty years and then achieve the ideal climate objective is fanciful. Curiously, some argue caps provide this outcome with certainty.

Either an emission target or a global price target will need adjusting many times, and it will be far easier to reset one price target than to renegotiate more than one hundred emission targets. Moreover the ultimate target should not be an emission level, but some climate variable such as a global temperature. It will be easier to set and meet such a longrange goal under a system of price commitments than a system of caps.

\section{NON-PRICE POLICIES}

Many emission-reduction policies do Inot price carbon. What will become of such policies? We hope many inappropriate subsidies will disappear because they are not rewarded, or in the case of fossil subsidies, because they are counted against carbon revenues. Others policies, such as fuel efficiency standards, could be recast as feebates, which are easily equated with carbon pricing.
(Feebates are revenue-neutral fee-and-rebate combinations based on, say, carbon emissions over an average auto lifetime.)

Other policies may be shoe-horned into the system with more difficulty and more risk of undermining the standard. But some policies will not be amenable to quantification as substitutes for carbon pricing. Fortunately, Green Fund payments, both positive and negative, will provide a uniform incentive for all countries to engage in such policies. Basing these payments purely on emissions-percapita, and not on say, historical emissions or income, maximizes the strength of the Green Fund incentive. Of course it should be equal in strength to the incentive provided by carbon pricing, so it will almost certainly be too weak. However, because Green Fund payments involve politically sensitive international monetary transfers, we believe the incentive for non-price polices will be given extra weight. Similarly, the Green Fund encourages the implementation of carbon pricing in the most effective manner.

Because non-price policies will be reasonably well motivated via the Green Fund, and because attempting to assign carbon 
prices to non-price policies (other than feebates) is the first step down the slippery slope to wasteful subsidies, we recommend that only taxes, caps and feebates be counted as carbon pricing.

\section{THE LOW COST OF CARBON PRICING}

arbon pricing, however implemented, is the most inexpensive policy that can define commitment to an international agreement. As explained above, the riskiness of committing to a cap means no country can count on the low cost of carbon pricing. Under capping, only the world as a whole is guaranteed a low cost. But with a global price target, each country is guaranteed a low cost, and that cost is so low that, if understood, it should greatly facilitate commitment.

In spite of the prominence of carbon pricing, a basic accounting of its costs is remarkably difficult to discover, perhaps because national costs are made uncertain by the need for international allowance trading. In the absence of such trading, national costs can be well approximated with a formula that the U.S. Environmental Protection Agency uses for exactly this purpose. ${ }^{3}$
This formula allows us to construct a simple example of carbon-pricing abatement costs. The example also includes the Green Fund assistance from industrialized countries to developing countries. The results are shown in Table 1.

Carbon pricing is assumed to reduce emissions by 20 percent from the amount shown. Note that China is quite close to being an average country in per-capita emissions.

The low costs in Table 1, given in cents per person per day, depend on three assumptions. First, the global carbon price is taken to be $\$ 30$ per ton. Second, the Green Fund incentive is assumed to be $\$ 2$ per ton of emissions above or below the world average per-capita emissions rate. Third, the resulting reduction in emissions is taken to be 20 percent. The first two assumptions are choices of the international community. But the amount of emission reduction for a fixed carbon price will undoubtedly differ from 20 percent. If the reduction were only 10 percent, the abatement costs would be cut in half. And if it were instead 40 percent, abatement cost would double, but this accomplishment at such a low cost would be stupendous. Hence no error in the assumption regarding the percent of emission reduction can change the results in a way that would tend to disrupt a climate agreement.

The conclusion must be that a strong climate policy can be extremely inexpensive. Even for the United States, the cost per person is less

\section{Costs of \$30/ton Global Carbon Pricing with a \$2/ton Green Fund}

\begin{tabular}{|c|c|c|c|c|}
\hline & $\begin{array}{l}\text { Starting Emissions } \\
\text { per Capita }\end{array}$ & $\begin{array}{c}\text { Emission Abate- } \\
\text { ment Cost }\end{array}$ & Green Fund Cost & Total Cost \\
\hline & (tons/year) & \multicolumn{3}{|c|}{ ( cents per person per day) } \\
\hline India & 1 & $0.8 \$$ & $-1.7 \&$ & $-0.9 \notin$ \\
\hline Average Country & 5 & $4.1 \$$ & $0.0 \notin$ & $4.1 \$$ \\
\hline United States & 20 & $16.4 \pitchfork$ & 6.64 & $23.0 \notin$ \\
\hline
\end{tabular}

Carbon pricing is assumed to reduce admissions by 20 percent from the amount shown. Note that China is quite close to being an average country in per-capita emissions. 
than a quarter per day ( $\$ 84$ per year), which is less than 1/5 of one percent of GDP. And this covers the cost of subsidizing low-emission countries such as India by roughly double their own abatement costs. These subsidies are onethird the level that EPA estimates for international subsidies under the Waxman-Markey bill. ${ }^{4}$ Perhaps some will argue that such low costs are still unfair to those who are poorest, yet if national policies are implemented with equal-per-person refunds, the poor will come out ahead.

If the carbon price of Table $1, \$ 30$ per ton, were implemented through 2020, the cost to China would make China wait until 13 July 2020 to be as rich as it would otherwise have been on 1 July $2020 .^{5}$ Since cost is the principle barrier to international agreement, allowing commitment to a global carbon price will greatly increase the chance of international agreement. And that will increase the chance of a significant commitment by the United States and others.

\section{CONCLUSION}

Tn 2007 Stiglitz doubted that we would "find an agreement acceptable to both the United
States and the developing countries within the Kyoto approach [to national caps]." The Copenhagen Accord confirms this. On the present course, the great bulk of future emissions increases will not be covered by carbon pricing. Instead we will depend on a suite of "Nationally Appropriate Mitigation Actions," selected and undertaken by developing countries but mainly funded by industrial countries. These multipurpose subsidies will likely prove particularly inefficient at reducing emissions.

The lack of comparable commitments on the part of major developing countries, and in particular the lack of comparable carbon pricing on goods produced using energy intensive technologies, will cause the U.S. Senate to balk at any significant level of carbon pricing by the United States. The combination of weak pricing in the United States and negligible carbon pricing in China will limit the willingness to commit in the rest of the industrialized world. In short the Kyoto approach of capping emissions has hit a dead end.

To overcome this, a new form of international commitment is necessary. That cannot be a commitment to a carbon tax because cap and trade has insurmountable political advantages in a number of industrial countries. Fortunately, caps at the domestic level can coexist with a price commitment at the international level. Meaningful and effective international commitments should be based on binding commitments to a single global carbon-price target. The approach is simple, effective, and remarkably affordable.

Letters commenting on this piece or others may be submitted at http://www.bepress.com/cgi/ submit.cgi? context=ev.

\section{NOTES}

1. The present proposal can be viewed as an extension of one made by Stiglitz (2006). The quote is from Stiglitz (2007).

2. See Stoft (2009a) for a slight modification of the Pricing Incentive formula that achieves budget balance each year.

3. US Environmental Protection Agency (EPA) (2009) EPA Analysis of the American Clean Energy and Security Act of 2009 H.R. 2454 in the 111th Congress," June 23, 2009 at 14.

4. The Green-Fund subsidy is $\$ 7$ billion per year compared with the EPA's $(2009,14)$ estimate of $\$ 20$ billion for foreign offsets in 2020.

5. This is based on the U.S. DOE's International Energy Outlook 2009, and documented on www.globalenergy.org.

The Economists' Voice www.bepress.com/ev February, 2010 


\section{REFERENCES AND FURTHER READING}

Cooper, Richard N. (2008) "The Case for Charges on Greenhouse Gas Emissions," The Harvard Project on International Climate Agreements, Discussion Paper, October. Available at: http:// belfercenter.ksg.harvard.edu/files/CooperWeb4. pdf.

Cramton, Peter and Steven Stoft (2009) "Global Carbon Pricing: A Better Climate Commitment," Global Energy Policy Center Research Paper, No. 09-06. Available at: http://www.globalenergy.org/lib.

Nordhaus, William D. (2008) A Question of Balance: Weighing the Options on Global Warming Policies. Chapter 8. New Haven, CN: Yale University Press.

Schelling, Thomas C. (2002) "What Makes Greenhouse Sense?" Foreign Affairs, 81(3):29. Available at: http://www.colorado.edu/ economics/morey/4545/global/schellingghsense.pdf.

Stiglitz, Joseph E. (2007) Making Globalization Work. Chapter 6. New York City, NY: W.W. Norton \& Co.

Stiglitz, Joseph E. (2006) "A New Agenda for Global Warming," The Economists' Voice 3(7):
Art. 3. Available at: http://www.bepress.com/ev/ vol3/iss $7 /$ art3.

Stoft, Steven E. (2009a) "Flexible Global Carbon Pricing: A Backward-Compatible Upgrade for the Kyoto Protocol," European Union Institute Working Papers, RSCAS 2009/35. Available at: http://papers.ssrn.com/abstract=1438182.

Stoft, Steven E. (2009b) "Beyond Kyoto: Flexible Carbon Pricing for Global Cooperation," Energy Policy Center Research Paper, No. 09-05. Available at: http://www.global-energy.org/lib.

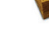

